\title{
PERBANDINGAN TEKNIK WARM DAN COLD START PADA MODEL WRF-3DVAR ASIMILASI DATA RADAR PADA PREDIKSI HUJAN LEBAT DI WILAYAH SURABAYA DAN SEKITARNYA
}

\section{Comparison of Warm and Cold Start Technique in WRF-3DVAR Radar Data Assimilation Models on Heavy Rain Prediction in Surabaya and Surrounding Areas}

\author{
Nayla Alvina Rahma ${ }^{1)^{\star}}$, Jaka Anugrah Ivanda Paski ${ }^{2)}$ \\ 1) Stasiun Meteorologi Kalianget Sumenep, Jln. Raya Kalianget Barat No. 8 Sumenep, 69471 \\ 2) Pusat Penelitian dan Pengembangan BMKG, Jl. Angkasa 1 No. 2 Kemayoran, Jakarta Pusat, 10720
} *E-mail: naylaalvinar@gmail.com

\begin{abstract}
Intisari
Penelitian ini bertujuan untuk mengetahui perbedaan hasil prediksi hujan WRF-3DVAR asimilasi data radar dengan menggunakan teknik warm start (spin-up 12 jam) dan cold start (tanpa spinup). Kejadian hujan yang dianalisis adalah kejadian hujan lebat tanggal 19-20 Januari 2019 di wilayah Surabaya dan sekitarnya. Data yang digunakan untuk simulasi adalah data Global Forescast System (GFS) dan data reflektivitas radar cuaca BMKG Surabaya produk Constant Altitude Plan Position Indicator (CAPPI). Analisis dilakukan dengan membandingan kondisi awal model pada parameter suhu dan kelembaban udara untuk mengetahui efek dari metode asimilasi data. Uji keandalan model dilakukan dengan melakukan verifikasi dikotomi (hujan/tidak hujan) hasil luaran model WRF dengan data hujan di 4 titik pengamatan, yaitu di Stasiun meteorologi Juanda, Stasiun meteorologi Perak, Stasiun Klimatologi Karangploso, dan Stasiun Geofisika Tretes. Hasil menunjukkan bahwa asimilasi data radar dengan mode cold start mempunyai hasil yang lebih baik dibandingkan dengan warm start, yang ditandai dengan lebih tingginya nilai Probability of Detection (POD) dan lebih rendahnya False Alarm Ratio (FAR). Asimilasi data dengan menggunakan mode cold start memiliki performa yang lebih baik dalam mendeteksi curah hujan per jam dengan ambang batas $>1 \mathrm{~mm}$ dan $>5 \mathrm{~mm}$, sedangkan curah hujan $>10 \mathrm{~mm}$ per jam lebih baik diprediksi menggunakan mode warm start.
\end{abstract}

Kata Kunci: Asimilasi Data, Warm Start, Cold Start, Hujan

\begin{abstract}
This research aims to determine the differences in the WRF-3Dvar rain forecast results with radar data assimilation using warms start (12 hours spin-up) and cold start (without spin-up) technique. The rainfall event analyzed is heavy rainfall on January 19-20, 2019, in Surabaya and surrounding areas. The data used for the simulation are the Global Forecast System (GFS) data and BMKG Surabaya weather radar reflectivity data from Constant Altitude Plan Position Indicator (CAPPI) products. The analysis is conducted by comparing the model's initial conditions on the parameters of temperature and humidity to determine the effects of the data assimilation method. The model reliability test was carried out by verifying the dichotomy (rain / no rain) of the WRF model output with rain data at 4 observation points, namely at the Juanda meteorological station, Perak meteorological station, Karangploso climatology station, and Tretes Geophysical Station. The results show that radar data assimilation with cold start technique has better results than a warm start, characterized by higher Probability of Detection (POD) values and lower False Alarm Ratios (FAR). Data assimilation using the cold start technique performs better in detecting hourly rainfall with thresholds $>1 \mathrm{~mm}$ and $>5 \mathrm{~mm}$, while rainfall $>10 \mathrm{~mm}$ per hour is better predicted using the warm start technique.
\end{abstract}

Keywords: Data Assimilation, Warm Start, Cold Start, Rain 


\section{PENDAHULUAN}

Prediksi cuaca numerik dapat memberikan informasi cuaca dengan cepat namun belum tentu akurat. Prakiraan yang menghasilkan prediksi cuaca yang sempurna kurang dari $20 \%$ (Kalnay, 2003). Kemampuan model numerik untuk memprediksi cuaca bukan hanya bergantung pada resolusi model dan keakuratan representasi pada proses-proses yang bekerja di atmosfer, namun juga bergantung pada kondisi awal (initial condition) dan syarat batas (boundary condition) yang digunakan pada proses integrasi model. Jadi, semakin akurat estimasi keadaan awal maka akan semakin baik kualitas prediksi yang nantinya dihasikan (Junnaedhi, 2008).

Salah satu cara untuk meningkatkan keakuratan hasil prediksi adalah melalui asimilasi data pada model WRF. Salah satu teknik dalam asimilasi data WRF yaitu Three Dimensional Variational (3DVAR), yang memiliki performa baik dalam menghasilkan analisis yang rasional terhadap kejadian hidrometeorologi (Barker et al., 2004). Data yang dapat digunakan untuk asimilasi terdiri dari berbagai jenis, yaitu data observasi berupa pengamatan sinoptik dan radiosonde, data radiasi satelit, dan data radar berupa data reflektivitas dan kecepatan radial (Sun dan Wang, 2013).

Asimilasi data yang dilakukan mendekati data observasi real-time tidak hanya menghasilkan performa yang lebih baik, meskipun model menyediakan kondisi awal yang buruk (Sokol dan Pesice, 2009), namun juga mampu menginisiasi fenomena cuaca skala konvektif (Sokol, 2010). Asimilasi data yang tepat, terutama untuk data radar, dapat meningkatkan akurasi prediksi curah hujan yang dihasilkan oleh model WRF (Liu, 2012).

Penelitian terkait asimilasi data menggunakan radar cuaca telah dilakukan oleh Gustari (2014) yang membuktikan bahwa asimilasi data radar mampu memperbaiki performa model dalam melakukan prediksi curah hujan. Paski (2016) memprediksi hujan di wilayah Lampung yang menunjukkan bahwa asimilasi menggunakan reflektivitas mempunyai prediksi distribusi spasial curah hujan yang paling baik meski masih overestimate dibandingkan data observasinya.

Asimilasi data radar pada penelitian ini dilakukan dengan menggunakan teknik sampling biggest yang merupakan teknik terbaik dalam memprediksi hujan lebat dengan menggunakan asimilasi reflektivitas radar (Satrya, 2012). Teknik ini juga digunakan oleh Paski et al. (2017) untuk memprediksi hujan lebat di wilayah Lampung dan menunjukkan perbaikan pada prediksi nilai spasial reflektivitas radar.
Penelitian dengan menggunakan asimilasi data radar produk CAPPI dilakukan oleh Paski et al. (2019) untuk memprediksi hujan di Jabodetabek dan menunjukkan bahwa asimilasi data reflektivitas berpengaruh terhadap pertumbuhan awan dan dapat memperbaiki prediksi curah hujan saat kejadian hujan ekstrem di Jabodetabek. Hastuti et al. (2019) melakukan penelitian serupa dan menyimpulkan bahwa perbaikan prediksi curah hujan dengan menggunakan data radar akan lebih terlihat di wilayah yang dekat dengan lokasi radar dan tidak terhalangi echo dari objek tetap serta akan lebih terlihat saat musim hujan.

Santi et al. (2019) melakukan asimilasi radar untuk prediksi hujan lebat di Jabodetabek dengan menggunakan metode Rapid Update Cycle (RUC) dengan waktu spin-up 12 jam dan menghasilkan performa yang lebih baik dibandingkan asimilasi tanpa RUC baik secara spasial maupun titik. Caceres dan Codina (2015) melakukan penelitian menggunakan teknik warm dan cold start pada asimilasi data radar dan menemukan bahwa teknik cold start memiliki performa terbaik dan lokasi yang lebih akurat dalam memprediksi curah hujan maksimal di Catalonia, namun prediksi yang dihasilkan cenderung underestimate.

Penelitian yang dilakukan memanfaatkan asimilasi data radar dengan menggunakan reflektivitas (Z) CAPPI, dimana teknik ini merupakan hal yang baru di Indonesia. Pada penelitian ini, dilakukan perbandingan asimilasi dengan teknik warm dan cold start. Teknik warm start dilakukan dengan mengasimilasikan data setelah proses spin-up selama 12 jam, sedangkan teknik cold start dilakukan tanpa proses spin-up. Diharapkan nantinya penelitian ini dapat menjadi pedoman dalam memprediksi hujan di wilayah Surabaya dengan menggunakan model WRF.

\section{METODE PENELITIAN}

Data masukan yang digunakan dalam penelitian ini adalah data Global Forecast System (GFS) dengan resolusi $0.25^{\circ} \times 0.25^{\circ}$ tanggal 19-20 Januari 2019 yang diperoleh dari https://rda.ucar.edu/datasets/ds084.1/index.html \#sfol-wl-/data/ds084.1. Data asimilasi yang digunakan adalah data reflektivitas radar cuaca milik BMKG Juanda pada tanggal 19 Januari 2019 pukul 00.00 UTC (07.00 LT). Penelitian ini dilakukan dengan teknik 3DVAR yang terdiri dari dua eksperimen model, yaitu model asimilasi data dengan menggunakan spin-up 12 jam (warm start) dan model kedua tanpa menggunakan spin-up (cold start) yang selengkapnya dapat dilihat pada gambar 1 . 


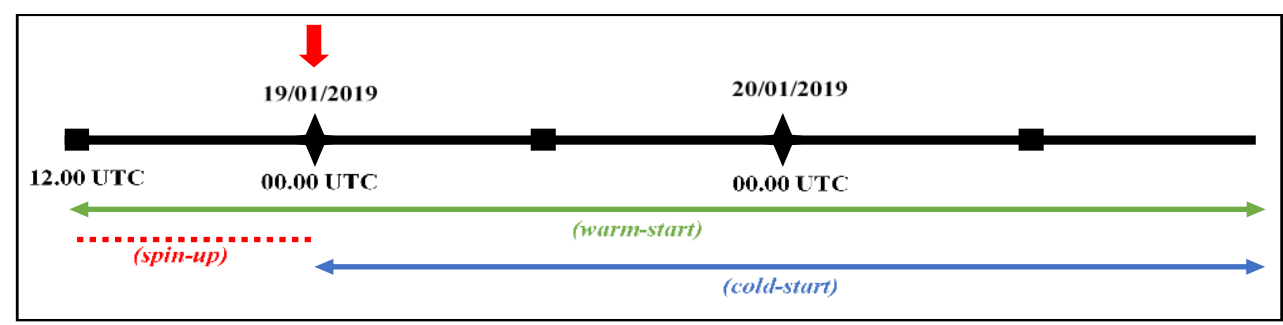

Gambar 1. Metode asimilasi data menggunakan mode warm-start dan cold-start. Panah merah menunjukkan waktu dilakukannya asimilasi data radar

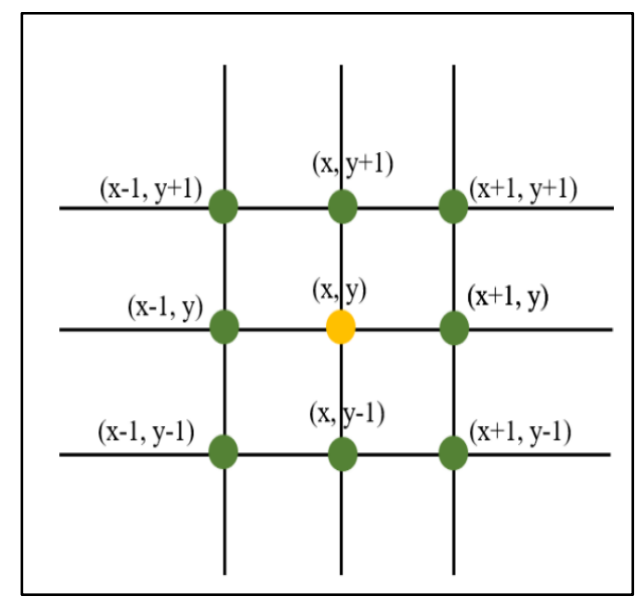

(a)

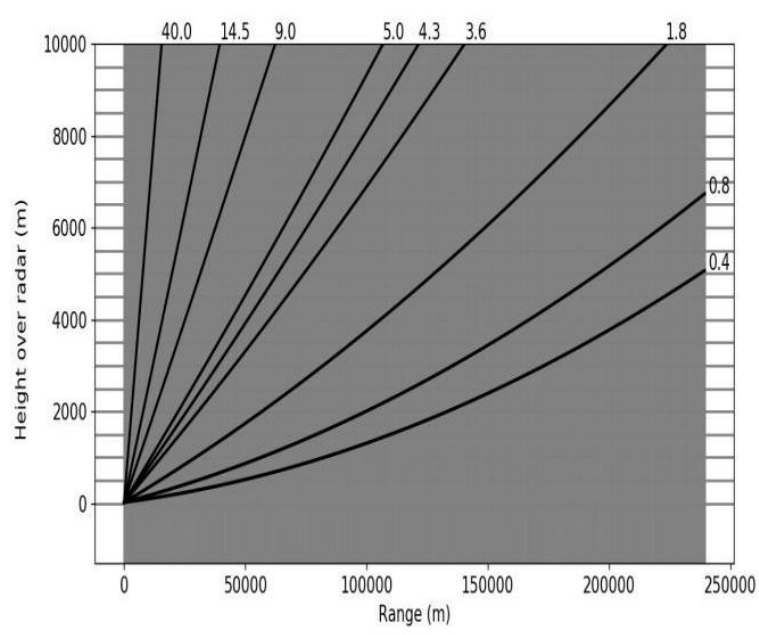

(c)

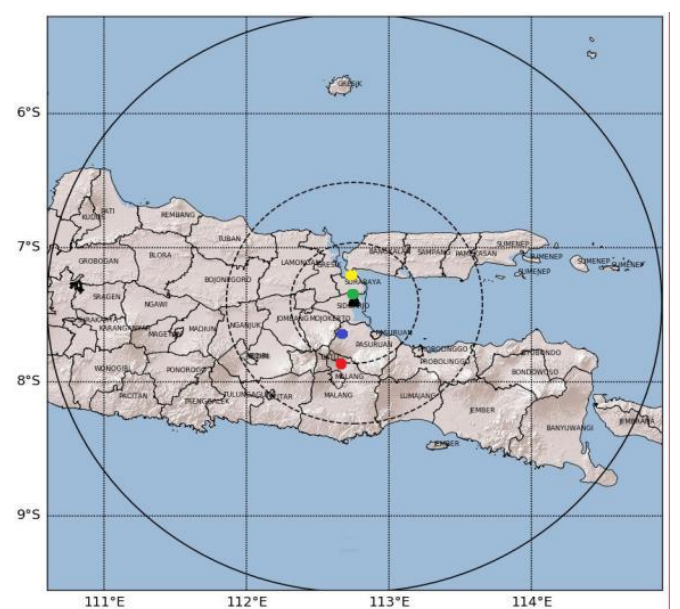

(b)

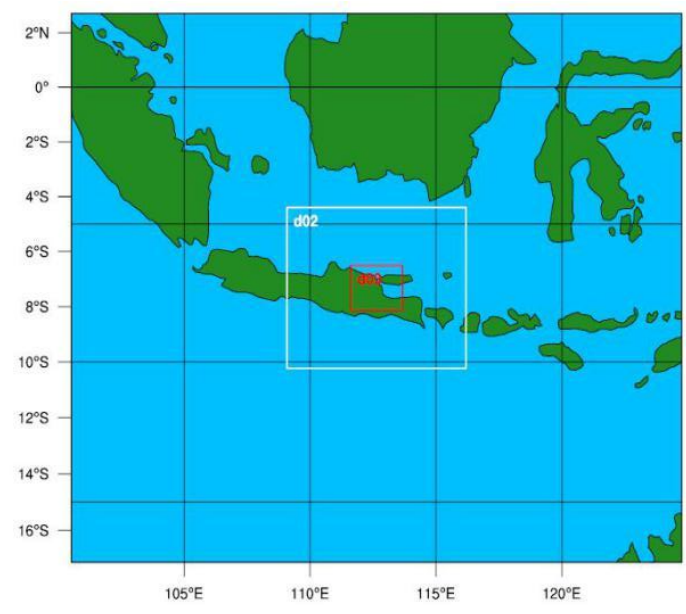

(d)

Gambar 2. (a) Posisi grid data untuk sampling curah hujan di titik (x, y); (b) Peta jangkauan radar cuaca Surabaya dengan posisi radar cuaca (kotak hitam), pos hujan Stasiun Meteorologi Juanda (Lingkaran hijau), Stasiun Meteorologi Perak (Lingkaran kuning), Stasiun Geofisika Tretes (Lingkaran biru), dan Stasiun Klimatologi Karangploso Malang (Lingkaran merah); (c) Scan Strategy pada radar cuaca Surabaya; (d) Domain penelitian pada model.

Analisis kondisi atmosfer sebelum kejadian hujan dilakukan dengan melihat data streamline angin dari ERA Interim ECMWF (https://apps.ecmwf.int/datasets/data/interim-fulldaily/) dan labilitas udara yang berasal dari hasil sounding BMKG Juanda. Kondisi awal model dianalisis dengan membandingkan parameter suhu dan kelembaban udara sebelum dan sesudah dilakukan asimilasi untuk mengetahui seberapa besar pengaruh dari asimilasi data pada masing-masing eksperimen. Uji performa model dilakukan per jam dengan teknik dikotomi (kejadian hujan/tidak hujan) menggunakan nilai hits, misses, false alarm, dan correct negatives yang kemudian diolah menjadi indeks Persen Correct (PC), Probability of Detection (POD), dan False Alarm Ratio (FAR), Probability of False Detection (POFD), dan bias untuk uji keandalan model prediksi.

Suatu wilayah prediksi didefinisikan terjadi hujan apabila salah satu titik atau stasiun pengamatan yang berada dalam wilayah 
tersebut mencatat hujan di atas $1 \mathrm{~mm}$ (Gustari et al., 2012). Hasil output model diverifikasi dengan membandingkan hujan hasil prediksi model asimilasi WRF dengan hujan hasil observasi. Intensitas hujan setiap eksperimen diperoleh dengan menerapkan sampling nilai rata-rata dari sembilan titik grid terdekat (Gambar 2a) karena memberikan hasil yang lebih baik dibandingkan nilai dari satu titik grid (Gustari et al., 2012). Keempat stasiun ini berada di dalam jangkauan radar cuaca milik BMKG Surabaya yaitu Stasiun Meteorologi Juanda (3 mdpl), Stasiun Meteorologi Perak (3 mdpl), Stasiun Geofisika Tretes (832 mdpl), dan Stasiun Klimatologi Karangploso Malang (590 mdpl) (Gambar 2b).

Hasil pada titik pos hujan verifikator masih dianggap baik dimana jangkauan maksimum dari produk reflektivitas radar adalah sekitar $240 \mathrm{~km}$ dari pusat radar (BMKG). Hal ini dapat dilihat dari Scan Strategy radar cuaca BMKG (Gambar 2c). Verifikasi curah hujan juga dilakukan secara spasial dengan membandingkan sebaran spasial hujan hasil GSMaP tipe standard (MVK) sebagai verifikator curah hujan secara spasial yang dapat diakses melalui http://sharaku.eorc.jaxa.cp.

Penelitian ini diolah dengan menggunakan WRF-ARW versi 4.1.2 dengan menggunakan 3 domain yang diperoleh melalui teknik downscaling dengan resolusi horizontal 1:3. Domain pertama memiliki resolusi sebesar 27 $\mathrm{km}$, domain kedua sebesar $9 \mathrm{~km}$, dan domain ketiga sebesar $3 \mathrm{~km}$ dengan titik pusat di $7.235^{\circ}$ LS dan $112.948^{\circ}$ BT (Gambar 2d). Jumlah level vertikal menggunakan 33 lapisan dapat meningkatkan akurasi prediksi intensitas hujan (Aligo et al., 2009). Konfigurasi model WRF sesuai dengan penelitian Rahma (2020) dapat dilihat pada tabel 1 .

\section{HASIL DAN PEMBAHASAN}

\subsection{Analisis kondisi atmosfer}

Analisis kondisi atmosfer dilakukan untuk mengetahui penyebab kejadian hujan yang terjadi di wilayah Surabaya dan sekitarmya. Analisis dilakukan dengan menggunakan data streamline angin gradien yang berasal dari ECMWF dan data labilitas udara hasil pengamatan radiosonde Stasiun Meteorologi Juanda.

Pada Tabel 2 memperlihatkan nilai indeks CAPE, Lifted Index, dan K-index yang digunakan untuk mengetahui kondisi labilitas atmosfer. CAPE adalah jumlah energi potensial yang dibutuhkan untuk mengangkat parsel udara pada proses konveksi, K-index dapat digunakan untuk mengetahui potensi terjadinya sistem konvektif, dan Lifted Index digunakan untuk mengetahui labilitas lingkungan Berdasarkan data radiosonde Stasiun Meteorologi Juanda tanggal 19 Januari 2019 pukul 00.00 UTC (07.00 LT), terlihat bahwa nilai CAPE, Lifted Index dan $K$ Index menandakan kondisi udara sangat labil sehingga mendukung proses pembentukan dan pertumbuhan awan khususnya awan konvektif penyebab terjadinya hujan (Grieser, 2012).

Tabel 1. Konfigurasi domain penelitian

\begin{tabular}{|l|l|}
\hline \multicolumn{1}{|c|}{ Konfigurasi } & \multicolumn{1}{c|}{ Keterangan } \\
\hline $\begin{array}{l}\text { Resolusi Grid } \\
\text { Horizontal }\end{array}$ & $\begin{array}{l}\text { Domain 1 =27 km } \\
\text { Domain 2 =9 km } \\
\text { Domain 3 = 3 km }\end{array}$ \\
\hline Skema Cumulus & Grell-Devenyi (GD) \\
\hline Skema Mikrofisis & Thompson \\
\hline $\begin{array}{l}\text { Skema Radiasi } \\
\text { Gelombang Panjang }\end{array}$ & $\begin{array}{l}\text { Rapid Radiative } \\
\text { (RRTM) Model }\end{array}$ \\
\hline $\begin{array}{l}\text { Skema Radiasi } \\
\text { Gelombang Pendek }\end{array}$ & $\begin{array}{l}\text { Rapid Radiative } \\
\text { Transfer Model } \\
\text { (RRTM) }\end{array}$ \\
\hline Skema Lapisan Batas & $\begin{array}{l}\text { Yonsei University } \\
\text { Scheme (YSU) }\end{array}$ \\
\hline Resolusi Temporal & 180 menit \\
\hline Jumlah Level Vertikal & 33 lapisan \\
\hline
\end{tabular}

Tabel 2. Nilai indeks labilitas atmosfer

\begin{tabular}{|l|l|}
\hline \multicolumn{1}{|c|}{ Indeks Labilitas } & \multicolumn{1}{c|}{ Nilai } \\
\hline CAPE & $1660 \mathrm{~J} / \mathrm{kg}$ \\
\hline Lifted Index & -3.6 \\
\hline K-Index & 37.8 \\
\hline
\end{tabular}

Pada gambar 3 dapat terlihat bahwa pada tanggal 19-20 Januari 2019 angin di wilayah Surabaya didominasi dari arah barat, bersesuaian dengan terjadinya angin monsun baratan pada bulan ini. Terdapat shearline di sekitar wilayah Surabaya yang dapat menyebabkan perlambatan massa udara sehingga dapat mengakibatkan terjadinya penumpukan massa udara dan pertumbuhan awan di wilayah tersebut. Saat hujan mulai turun pada tanggal 19 Januari 2019 pukul 00.00 UTC (07.00 LT), kecepatan angin berkisar 2-6 knot dan pukul 12.00 UTC (19.00 LT) kecepatan angin meningkat pada kisaran 4-8 knot. Keesokan harinya pada tanggal 20 Januari 2018 pukul 00.00 UTC kecepatan angin menurun menjadi 2-6 knot dan meningkat kembali menjadi 6-14 knot pukul 12.00 UTC (19.00 LT). 

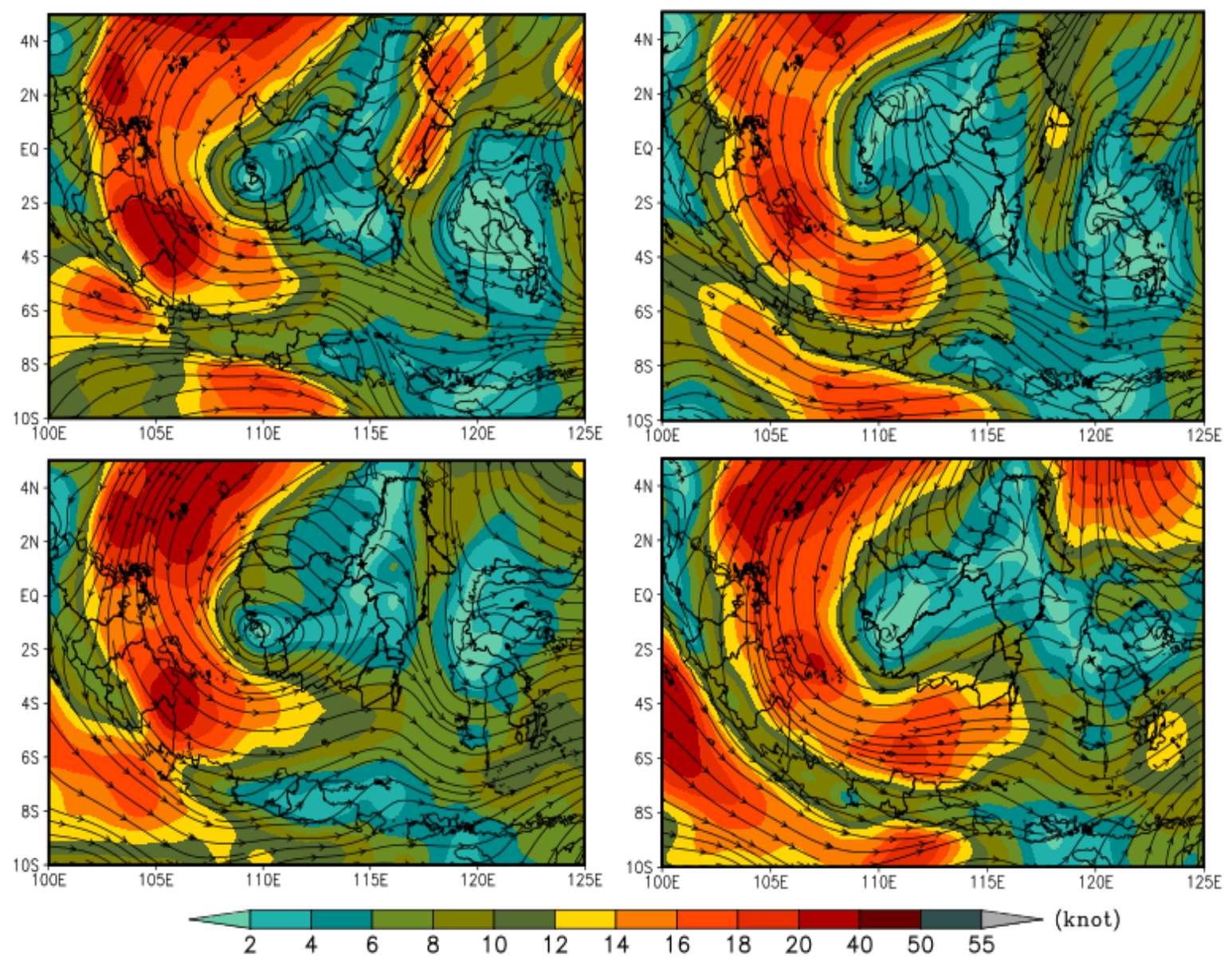

Gambar 3. Vektor angin gradien tanggal 19 Januari 2019 pukul 00.00 UTC (07.00 LT) (a), 12.00 UTC (19.00 LT) (b), 20 Januari 2019 pukul 00.00 UTC (07.00 LT) (c), 12.00 UTC (19.00 LT) (d)

\subsection{Analisis kondisi awal model}

Pengaruh asimilasi data terhadap kondisi awal model dilakukan dengan menggunakan analisis increment. Increment adalah perbedaan kondisi awal model yang telah asimilasi terhadap kondisi awal model tanpa asimilasi. Berikut akan ditampilkan increment masing-masing kasus pada parameter suhu dan kelembaban udara di lapisan permukaan. Hal ini dilakukan untuk mengetahui kemampuan kondisi awal model. Jika data memberikan nilai yang sama, maka menandakan kondisi awal model tidak bisa digunakan.

Berdasarkan gambar 4, terlihat bahwa pada kedua eksperimen umumnya terjadi perbedaan suhu udara di seluruh domain, terutama untuk wilayah yang topografinya cukup tinggi seperti wilayah pegunungan di bagian selatan dari domain model. Bagian selatan dari domain model merupakan dataran tinggi seperti pegunungan Bromo, pegunungan ArjunoWelirang, pegunungan Kawi dan pegunungan Liman. Hal ini menandakan bahwa model WRF mampu memperhitungkan pengaruh topografi di wilayah penelitian, terlihat dari perubahan nilai yang signifikan pada dataran tinggi di wilayah penelitian. Increment antara eksperimen warm start dan cold start memiliki pola yang tidak jauh berbeda, namun untuk wilayah Surabaya dan sekitarnya (kotak merah) dapat terlihat bahwa eksperimen cold start mengalami peningkatan suhu yang lebih luas dibandingkan dengan warm start.

Hasil increment terhadap parameter kelembaban udara pada gambar 5 menunjukkan bahwa asimilasi radar memiliki dampak yang signifikan terhadap kondisi awal model. Xiao et al. (2007) menyimpulkan bahwa data reflektivitas radar memiliki dampak langsung pada analisis suhu udara dan kelembaban udara. Untuk wilayah Surabaya, tidak terdapat perbedaan nilai increment kelembaban udara pada kedua eksperimen setelah dilakukan asimilasi data radar. Penurunan nilai kelembaban udara pada eksperimen warm start lebih signifikan dibandingkan eksperimen cold start terlihat di wilayah perairan antara Pulau Jawa dan Pulau Madura (timur - tenggara dari kotak merah). 


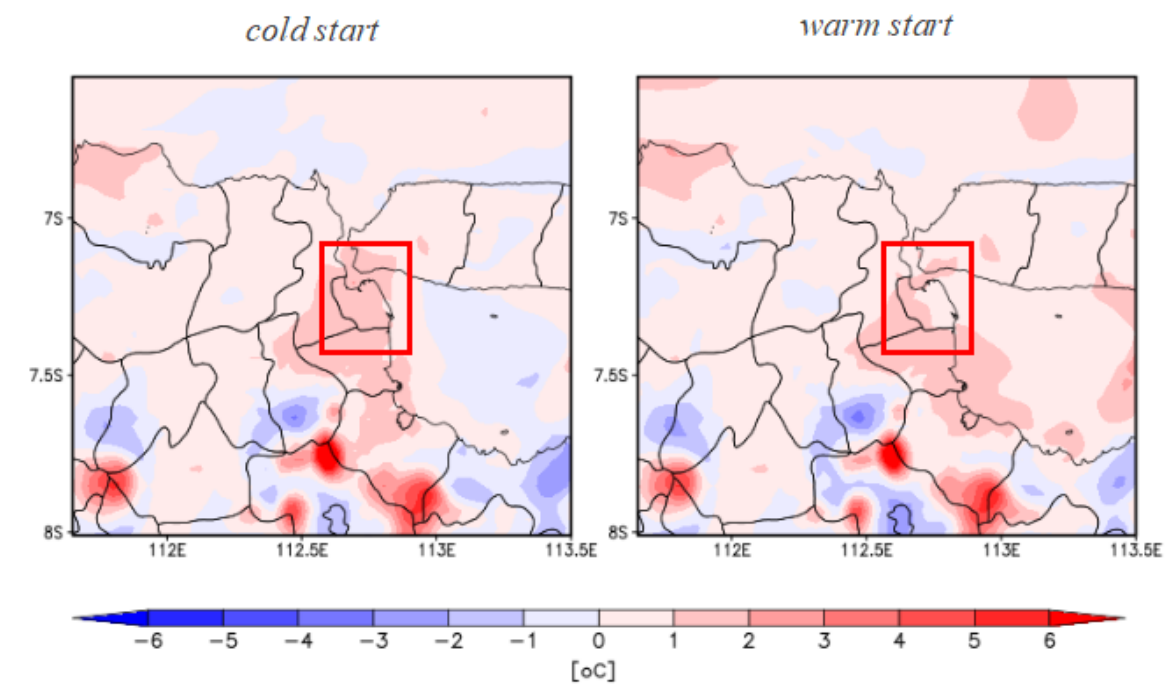

Gambar 4. Increment suhu udara tanggal 19 Januari 2019 pukul 00.00 UTC (07.00 LT)

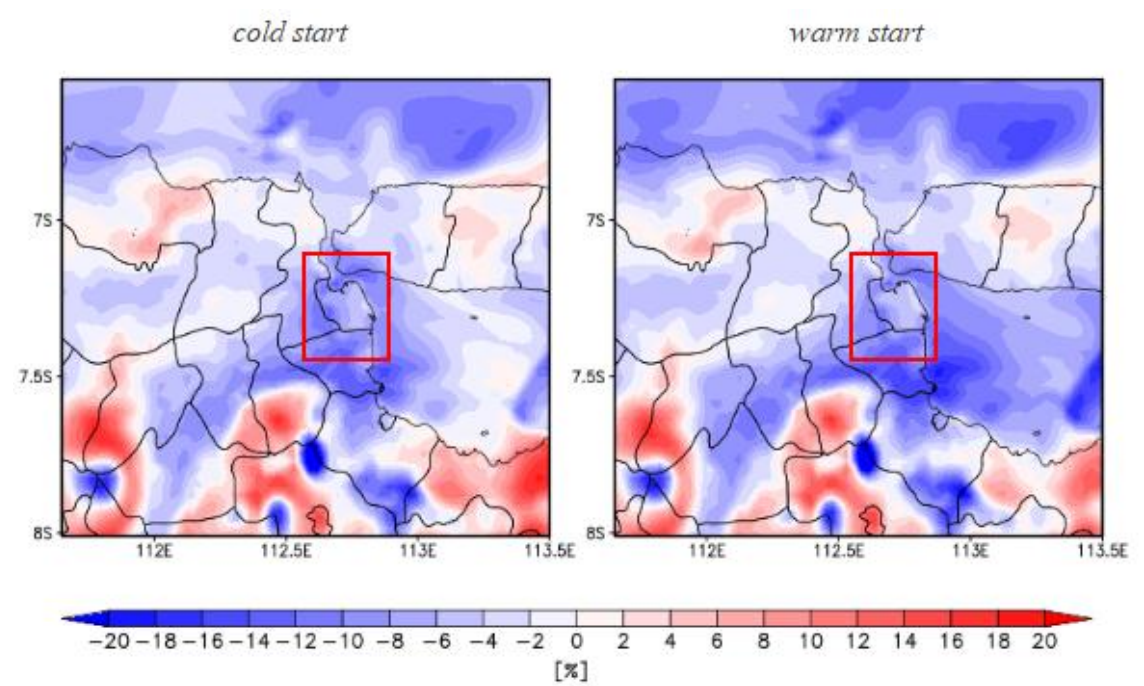

Gambar 5. Increment kelembaban udara tanggal 19 Januari 2019 pukul 00.00 UTC (07.00 LT)

\subsection{Perbandingan hasil prediksi keluaran model}

Sebaran spasial hujan hasil estimasi GSMaP dan asimilasi data radar WRF pada tanggal 19 dan 20 Januari 2019 ditampilkan pada gambar 6 . Hujan yang dihasilkan oleh estimasi GSMaP tanggal 19 Januari 2019 memiliki luasan yang cukup luas dibanding kelima model eksperimen asimilasi data radar, dimana hampir seluruh domain terjadi hujan. Curah hujan tertinggi di wilayah daratan terjadi di wilayah Surabaya dan Malang dengan intensitas mencapai $90 \mathrm{~mm} / \mathrm{hari}$. Hal yang sama juga terlihat pada tanggal 20 Januari 2019, namun intensitas hujan yang ditampilkan GSMaP lebih rendah dibandingkan hari sebelumnya. Sebaran hujan hasil ekperimen asimilasi data memiliki wilayah yang lebih sempit dan berpisah-pisah, namun intensitasnya lebih tinggi dibanding hujan estimasi GSMaP.

Berdasarkan analisis curah hujan secara spasial, terlihat bahwa semua model eksperimen belum mampu menggambarkan spasial hujan yang dihasilkan oleh estimasi GSMaP. Curah hujan yang dihasilkan model eksperimen cenderung memiliki wilayah yang lebih sempit dan tersebar secara tidak merata di seluruh wilayah domain dibandingkan dengan hujan hasil GSMaP yang hujannya cenderung terpusat pada satu luasan. Hal ini diakibatkan oleh perbedaan resolusi spasial, dimana pada GSMaP menggunakan resolusi $0,1^{\circ}(+10 \mathrm{~km})$, sedangkan pada penelitian ini menggunakan resolusi domain hingga $3 \mathrm{~km}$.

Selain menggunakan analisis spasial hujan, verifikasi data prediksi juga menggunakan data prediksi kejadian dikotomi (hujan/tidak hujan) pada tanggal 19-20 Januari 2019 ditampilkan pada tabel 3 . Tabel 3 menunjukan bahwa jumlah masing-masing kejadian baik hits, misses, false alarms, dan correct negatives antara eksperimen asimilasi dengan teknik cold start dan warm start memiliki perbedaan yang kurang signifikan, yaitu hanya berbeda 2 kejadian. Ekperimen yang dapat mendeteksi kejadian hujan (hits) terbanyak dimiliki oleh eksperimen cold start, namun jumlah false alarm 

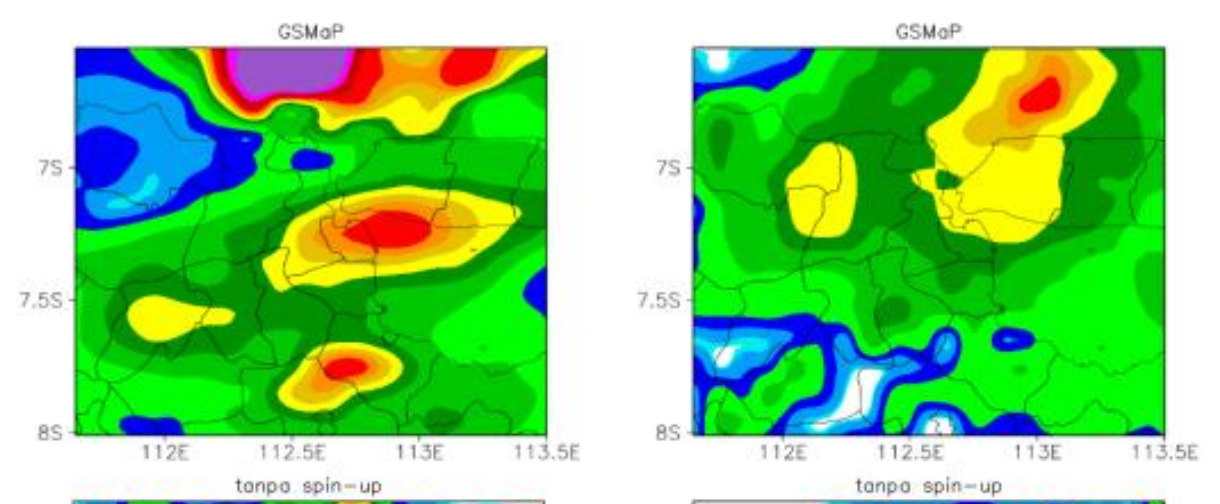

(mm/hari)
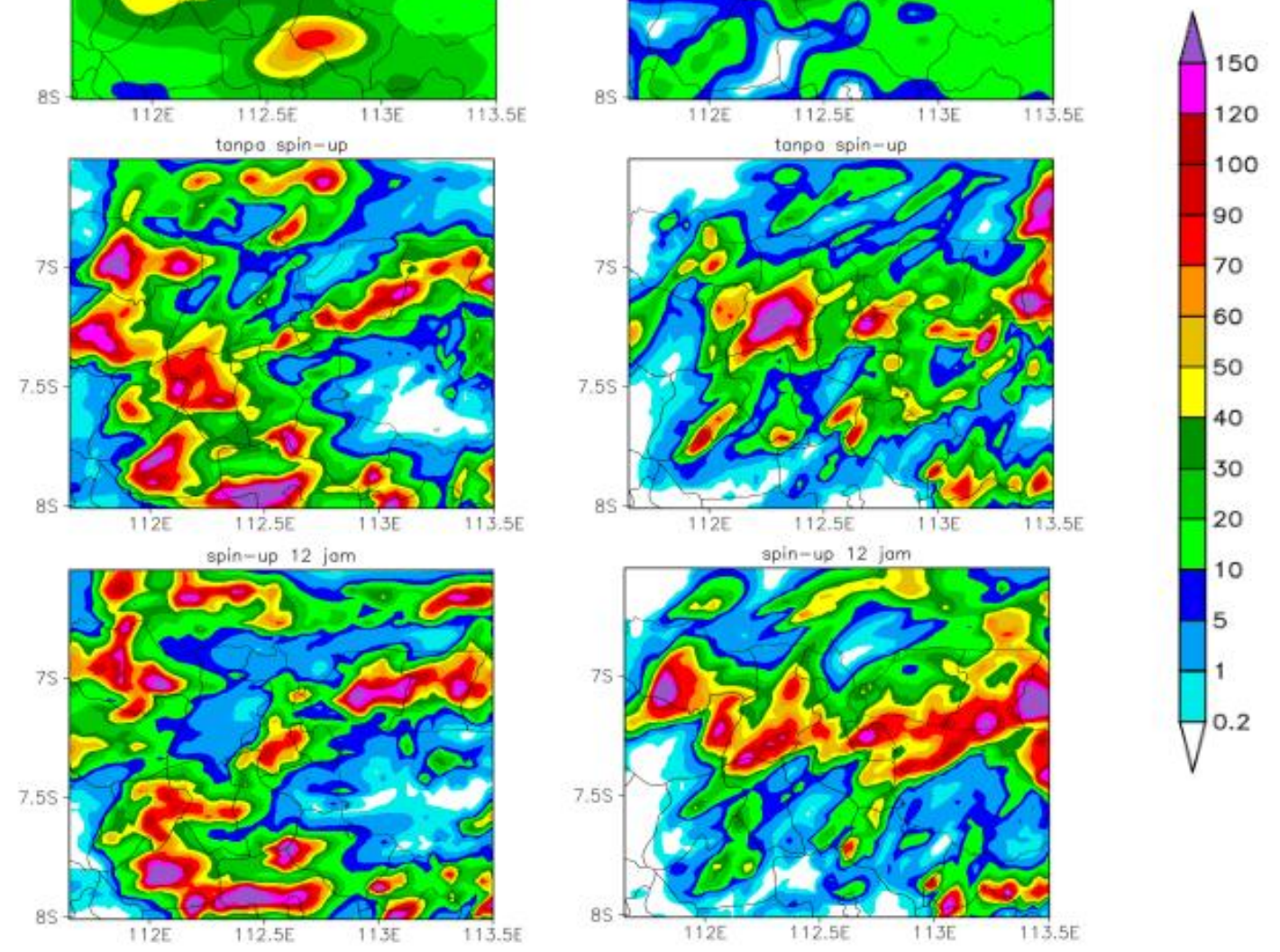

Gambar 6. Spasial curah hujan antara hasil prediksi GSMaP dengan asimilasi data radar tanpa spin-up dan spin-up 12 jam tanggal 19 Januari 2019 (kiri) dan 20 Januari 2019 (kanan)

Tabel 3. Jumlah prediksi kejadian

\begin{tabular}{|l|c|c|}
\hline \multicolumn{1}{|c|}{ Nilai } & Cold start & Warm start \\
\hline Hits & 17 & 15 \\
\hline Misses & 15 & 17 \\
\hline False Alarms & 38 & 36 \\
\hline Correct Negatives & 126 & 128 \\
\hline
\end{tabular}

yang dihasilkan lebih tinggi dibandingkan eksperimen dengan warm start. Semakin tinggi nilai jumlah false alarms maka menandakan bahwa eksperimen tersebut underforecasting.

Untuk mengetahui kemampuan prediksi masing-masing eksperimen, dilakukan uji keandalan dengan menggunakan Persen Correct (PC), Probability of Detection (POD), dan False Alarm Ratio (FAR), Probability of False Detection (POFD), dan Bias lalu ditampilkan melalui histogram seperti yang ditunjukkan pada gambar 7. Berdasarkan gambar tersebut dapat terlihat bahwa nilai PC yang dihasilkan kedua eksperimen adalah sama yang menandakan bahwa kedua eksperimen memiliki kemampuan yang sama dalam memprediksi kejadian dengan benar, namun nilai POD yang dimiliki oleh eksperimen asimilasi cold start lebih tinggi dibandingkan warm start dengan selisih $6 \%$. Meskipun teknik cold start memiliki kemampuan prediksi yang lebih baik dibandingkan warm start namun nilai bias yang dihasilkan lebih tinggi, yaitu mencapai 1,7. Kedua eksperimen memiliki nilai bias melebihi 1 yang menandakan bahwa prediksi hujan yang dihasilkan lebih banyak dibandingkan dengan data observasi (overforecasting). Nilai POD dan POFD selanjutnya diplot ke dalam kurva ROC agar dapat mengetahui eksperimen mana yang memiliki performa yang paling baik dalam mendeteksi intensitas hujan dari berbagai ambang batas yang telah ditentukan.

Melalui kurva ROC yang ditampilkan pada gambar 8, dapat terlihat bahwa kedua eksperimen masih mampu memprediksi curah hujan per jam dengan ambang batas $>1 \mathrm{~mm},>5$ $\mathrm{mm}$, dan $>10 \mathrm{~mm}$. Teknik cold start memiliki performa prediksi yang lebih baik dibandingkan asimilasi menggunakan teknik warm start dalam 
memprediksi curah hujan dengan ambang batas $>1 \mathrm{~mm}$ dan $>5 \mathrm{~mm}$, namun curah hujan $>10 \mathrm{~mm}$ per jam dapat diprediksi dengan baik oleh teknik asimilasi warm start.

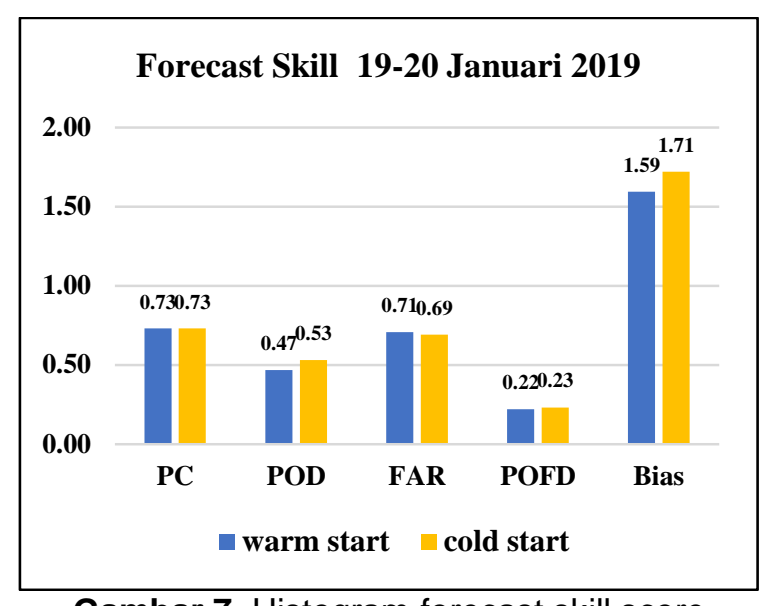

Gambar 7. Histogram forecast skill score tanggal 19-20 Januari 2019

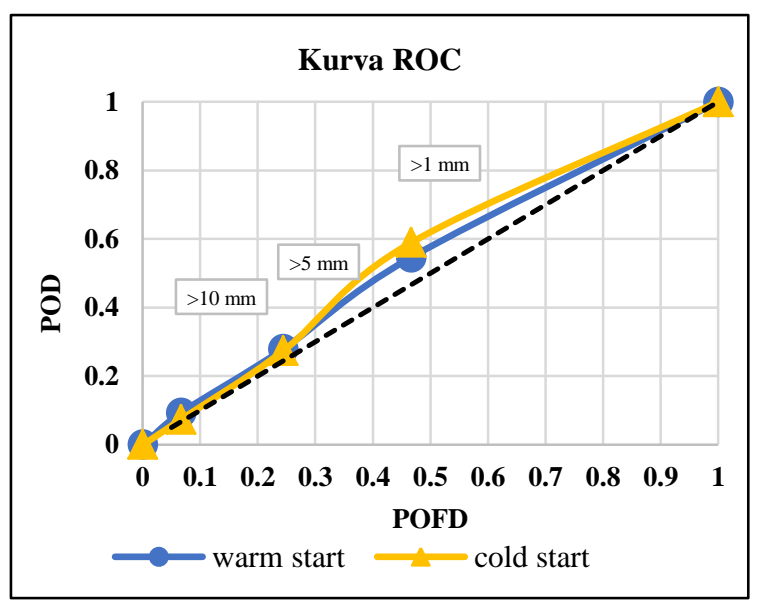

Gambar 8. Kurva ROC kejadian hujan tanggal 19-20 Januari 2019

\section{KESIMPULAN}

Berdasarkan hasil dari pembahasan, asimilasi WRF dengan menggunakan data radar memiliki pengaruh terhadap perubahan kondisi awal model terutama parameter suhu dan kelembaban udara yang digambarkan oleh nilai increment setiap parameter. Hasil dari analisis kedua eksperimen asimilasi data dengan teknik warm start dan cold start masih belum mampu memprediksi curah hujan secara spasial dengan baik. Namun, asimilasi data radar dengan teknik cold start memiliki performa yang lebih baik dibandingkan teknik warm start jika dilihat dari analisis uji keandalan dengan menggunakan beberapa nilai uji yaitu PC, POD, FAR, POFD dan Bias. Dari analisis ROC menunjukan Teknik cold start memiliki performa prediksi yang lebih baik dalam memprediksi curah hujan dengan ambang batas $>1 \mathrm{~mm}$ dan $>5 \mathrm{~mm}$.
Saran. Perlu adanya analisis lebih lanjut dengan melakukan penambahan kasus beberapa hujan lebat di wilayah Surabaya. Selain itu, pemilihan kasus hujan dilakukan pada hujan yang sebarannya lebih merata dalam skala ruang.

\section{DAFTAR PUSTAKA}

Aligo, E.A., Gallus, W.A., Segal, M. (2009). On the Impact of WRF Model Vertical Grid Resolution on Midwest Summer Rainfall Forecasts. Weather and Forecasting 24(2). 575-594.

doi: 10.1175/2008WAF2007101.1

Barker, D. M., Huang, W., Guo, Y.-R., Boourgeous, A. J., Xiao, Q. N. (2004). A Three-Dimensional Variational Data Assimilation System for MM5: Implementation and Initial Results. Monthly Weather Review. 132, 897-914.

Cáceres \& B. Codina. (2018). Radar data Assimilation Impact Over Nowcasting A Mesoscale Convective System In Catalonia Using The WRF Model. Tethys, Journal of Weather and Climate of the Western Mediterrania. 2018(15), 3-17. doi: 10.3369/tethys.2018.15.01

Grieser, Jürgen. (2012). Convection Parameters. Germany: Selbstverl.

Gustari, I., Hadi T. W., Hadi S., Renggono F. (2012). Akurasi Prediksi Curah Hujan Harian Operasional di Jabodetabek: Perbandingan dengan Model WRF. Jurnal Meteorologi dan Geofisika 13(2). 119-130. doi: 10.31172/jmg.v13i2.126

Gustari, I. (2014). Perbaikan Prediksi Cuaca Numerik Kejadian Hujan Sangat Lebat Terkait dengan Sistem Awan di Jabodetabek Menggunakan Asimilasi Data Radar C-Band. Disertasi. Institut Teknologi Bandung.

Hastuti, M. I., Paski, J. A. I., Fatkhuroyan. (2019). Improving Numerical Weather Prediction of Rainfall Using Radar Data Assimilation. Indonesian Journal of Geography. 51(3). 273-284. doi: 10.22146/ijg.44924

Junnaedhi, I.D. (2008). Pengaruh Asimilasi Data dengan Metode 3DVAR Terhadap Hasil Prediksi Cuaca Numerik di Indonesia. Thesis. Meteorologi ITB. Bandung.

Kalnay, E. (2003). Atmospheric Modeling, Data Assimilation, and Predictability. Cambridge: Cambridge University Press.

Liu, Jia, Bray, M.T.J., Han, D. (2012). Exploring The Effect of Data Assimilation by WRF3DVAR for Numerical Rainfall Prediction with Different Types of Storm Events. Hydrological Processes, 27(25). Doi: 10.1002/hyp.9488

Paski, J. A. I. (2016). Pengaruh Asimilasi Data Radar C-Band dalam Prediksi Cuaca 
Numerik (Studi Kasus di Lampung). Skripsi. Meteorologi. STMKG. Jakarta.

Paski, J. A. I. dan Gustari, I. (2017). Pengaruh Asimilasi Data Radar Cuaca Dalam Prediksi Cuaca Numerik di Provinsi Lampung (Studi Kasus 28 Februari 2015). Jurnal Meteorologi Klimatologi dan Geofisika. 18(2), 55-64. doi: 10.31172/jmg.v18i2.361

Paski, J. A. I., Permana, D. S., Hastuti, M. I., Sudewi, R. S. S. (2019). Dampak Asimilasi Data Radar Produk Cappi pada Prediksi Kejadian Hujan Lebat di Jabodetabek Menggunakan Model WRF-3DVAR. Jurnal Meteorologi dan Geofisika, 20(1), 47. Doi: 10.31172/jmg.v20i1.605

Rahma, Nayla Alvina. (2020). Perbandingan Asimilasi Data pada Model WRF-ARW untuk Prediksi Curah Hujan di Wilayah Surabaya dan Sekitarnya. Skripsi. Skripsi. Meteorologi. STMKG. Jakarta.

Santi, N. V., Paski, J. A. I., Mulsandi, A. (2019). Improvement of Numerical Weather Prediction of Heavy Rain Event Using Radar Data Assimilation Using Rapid Update Cycle Method in Jabodetabek Region. IOP Conference Series: Earth and Environmental Science, 399(1). doi: 10.1088/1755-1315/399/1/012124
Satrya, L. I. (2012). Asimilasi Data Radar dalam Penerapan Prediksi Cuaca Numerik di Indonesia (Studi Kasus di Jawa Barat). Skripsi. Meteorologi ITB. Bandung.

Sokol, Z., Pesice, P. (2009). Comparing Nowcastings of Three Severe Convective Events by Statistical and NWP Models. Atmospheric Research 93(1), 397-407. doi: 10.1016/j.atmosres.2008.09.016

Sokol, Z. (2010). Assimilation of Extrapolated Radar Reflectivity Into A NWP Model and Its Impact on A Precipitation Forecast at High Resolution. Atmospheric Research 100, 201-212. Doi: 10.1016/j.atmosres.2010.09.008

Sun, J., Wang, H. (2013). Radar Data Assimilation with WRF 4D-Var. Part II: Comparison with 3D-Var for a Squall Line over the U.S. Great Plains. Monthly Weather Review, 141(7), 2245-2264. doi: 10.1175/MWR-D-12-00169.1

Xiao, Q., Kuo, Y. H., Sun, J., Lee, W. C., Barker, D. M., Lim, E. (2007). An Approach of Radar Reflectivity Data Assimilation and Its Assessment with The Inland QPE of Typhoon Rusa (2002) at Landfall. Journal of Applied Meteorology and Climatology. 46(1). 14-22. doi:10.1175/JAM2439.1 